\title{
AZ AUTÓ-MÁRKAKERESKEDÉSEK JELENLEGI HELYZETE MAGYARORSZÁGON
}

\author{
Turzai-Horányi Beatrix
}

\begin{abstract}
Absztrakt: Az autó jelentősen átalakította a világot, amikor több mint száz évvel ezelőtt, gyakorlatilag új korszakot nyitott az emberi civilizációban és a társadalmi viszonyokban. Habár kezdetekben csak szük kör kiváltsága volt, napjainkra nemcsak a környezetünkre, de a világgazdaság egészére is ugyanúgy hatással van. A gépjármügyártás, az autókereskedelem, a javító - karbantartó bontó tevékenység és a kapcsolódó szolgáltatások széles köre közvetve az egész társadalom érdekeit szolgálják. Magyarországon a '90-es években zajlott a márkakereskedői hálózat kiépítése. Ezekben az években a kereskedők többsége önálló mühellyel és szakmai kapcsolatokkal is rendelkezett, a kereskedések pedig zömmel több telephellyel müködő családi vállalkozások voltak. A 2000-es évek elején az értékesítési hálózat túlméretezetté vált és a struktúrája sem volt elég hatékony. A kereskedések magas számával a verseny is erősödött, emellett komoly fejlesztési követelményeknek is meg kellett felelniük. A gépjármükereslet a vásárlások ösztönzése révén folyamatosan, lendületesen növekedett, a személygépkocsi-állomány 2009-re már a hárommilliót is meghaladta, mígnem 2009ben beszakadt a piac. A 2008-ban indult világgazdasági válság leginkább az ingatlanpiacon és a személygépjármü piacon éreztette negatív hatását. A finanszírozási lehetőségek csökkenését eredményezte a likviditás drasztikus csökkenése is, amelynek következményeként a lakosság zömmel elhalasztotta a gépkocsi vásárlásokat. Ennek köszönhetően az elmúlt 10 évben nemcsak az autószalonok és a tulajdonosok száma változott meg, hanem az új autók számának forgalomba helyezése is jelentősen lecsökkent, de az elmúlt néhány évben már újra növekvő tendenciát mutat. A 2000-es évek mesterséges keresletnöveléséhez képest a szakemberek szerint ugyanakkor ez a jelenlegi helyzet sokkal reálisabb az autópiac számára.

Vizsgálatom során, a szekunder adatok elemzését követően célzott primer kutatást is végeztem, melynek segítségével megpróbáltam feltárni, majd értékelni a magyarországi autómárkakereskedések helyzetét és jelenlegi problémáit.

A márkakereskedések helyzetéről végzett 2017-es felmérés alapján elmondható, hogy folytatódnak Magyarországon a koncentrációs és konszolidációs folyamatok, ugrásszerü változások az elmúlt 2 évben nem történtek. Egyre fontosabbá válik az autókereskedések számára, hogy a vásárlókkal egy szoros kapcsolatrendszert alakítsanak ki és próbáljanak minél inkább az új mobilitási trendekhez alkalmazkodni. A digitális élmény, az autókereskedés elhelyezkedése, az internetelérhetőség, illetve a vásárlást követő élmény mind mind egyre inkább befolyásoló tényező lesz az autókereskedések versenyképességét illetően.
\end{abstract}

Abstract: Cars significantly restructured the world, when practically opened a new period in human civilisation and social relations more than one hundred years ago. Although, it was the privilege of a limited group at the beginning, by now, it affects not only our environment but the whole world economy. Car manufacturing, car trading, repairing - maintaining - and demolition activities and broad range of related services serve the interests of the whole society in an indirect way. In Hungary, building of dealership network was also ongoing in the '90s. In these years the majority of dealers had their own repair shops and professional relations, and dealerships were mainly family businesses operating at more sites. At the beginning of the years 2000, the sales network became oversized and its structure was not efficient enough either. The high number of dealerships led to an increasing competition, meanwhile dealerships also had to comply with serious development requirements. Due to the stimulation of purchasing, the demand for vehicles continuously raised, passenger car fleet reached 3 million pieces by 2009, when the market collapsed. The crisis, started in 2008, has affected negatively in particular the real estate and passenger automotive industry. Dramatic decline of liquidity also resulted in the fall of financing possibilities, as a consequence of which, people postponed their intention of purchasing cars. Due to this, not only the number of showrooms and owners changed in the last 10 years, but the number of new cars registered also dropped significantly, 
although shows increasing tendency again in the recent years. Comparing to the artificial increasing of demand in the years 2000, experts consider the current situation more realistic for car market.

In my publication, following to the analysis of secondary data, I carried out targeted primary research during my research, with the help of which I attempted to explore, analyse and assess the situation and current problems of Hungarian dealerships.

Based on the results of the survey carried out in 2017 on the situation of dealerships, it can be claimed that concentration and consolidation procedures are continuous, there have been no bigger changes in the last 2 years. Establishing close relationship with customers is getting more important for dealerships, as well as to be able to adjust themselves to the new mobility trends as much as possible. Digital experiences, location of the dealership, internet access and post-purchase experience will all be influencer factors regarding the competitiveness of dealerships.

Kulcsszavak: autóipar, márkakereskedés, autóértékesítés, versenyképesség

Keywords: automotive industry, car dealership, car sales, competitiveness

\section{Bevezetés}

A '90-es években a termékpiaci átalakulásokkal és az importcégek és gyárak betelepedéseivel egyidőben zajlott az országban a márkakereskedői hálózat kiépítése is. Ezekben az években a kereskedők többsége önálló mühellyel és szakmai kapcsolatokkal is rendelkezett, a kereskedések pedig zömmel több telephellyel müködő családi vállalkozások voltak. A 2000-es évek elején az értékesítési hálózat túlméretezetté vált - szakemberek szerint három-négyszerese az indokoltnak - és a struktúrája sem volt elég hatékony. A kereskedések magas számával a verseny növekedett, akiknek mindeközben komoly fejlesztési követelményeknek is meg kellett felelniük. A gépjárműkereslet a vásárlások ösztönzése révén folyamatosan, lendületesen növekedett, mígnem 2009-ben beszakadt a piac. 2002-2009 között közel 15 százalékkal nőtt a személygépkocsi-állomány, ami 2009-re már a hárommilliót is meghaladta. Ezekben az években a kereskedők a modern marketingfogásokkal és a gépjármüfinanszírozási módszerek használatával tömegeket tettek új autók tulajdonosává, olyanokat is, akik enélkül csak olcsó, haszált autót tudtak volna megvásárolni. A kereskedések egy része, a válság előtti években, csak az értékesítéssel foglalkozott, és a bónusz mellett a hiteljutalékra összpontosított. (Pásztor, 2011)

2017-ben a magyarországi autóállomány már ismét meghaladta a 3 milliót, ugyanakkor az autók átlagéletkora nem javul. A 2008-as válság kirobbanása előtt már majdnem 10 év alattira csökkent a sok újautó értékesítése miatt, de mára 13,9 évvel eléri az elmúlt 28 év csúcsát. Az elmúlt 10 évben a visszaesés az autóértékesítések csökkenése miatt történt, illetve a válságból való kilábalást követően is a használtautó-importból származó eladások nőttek nagyobb arányban. Az első alkalommal forgalomba helyezett autók esetében is látható a használtautók dominanciája. (1. ábra) (Internet 1)

Ugyanakkor a Datahouse Kft. adatbázisa alapján még mindig $60 \%$ feletti a behozott autókon belül a 10 évnél idősebbek aránya. 


\section{1. ábra: Az első alkalommal forgalombahelyezett új- és használtautók száma} (ezer db)

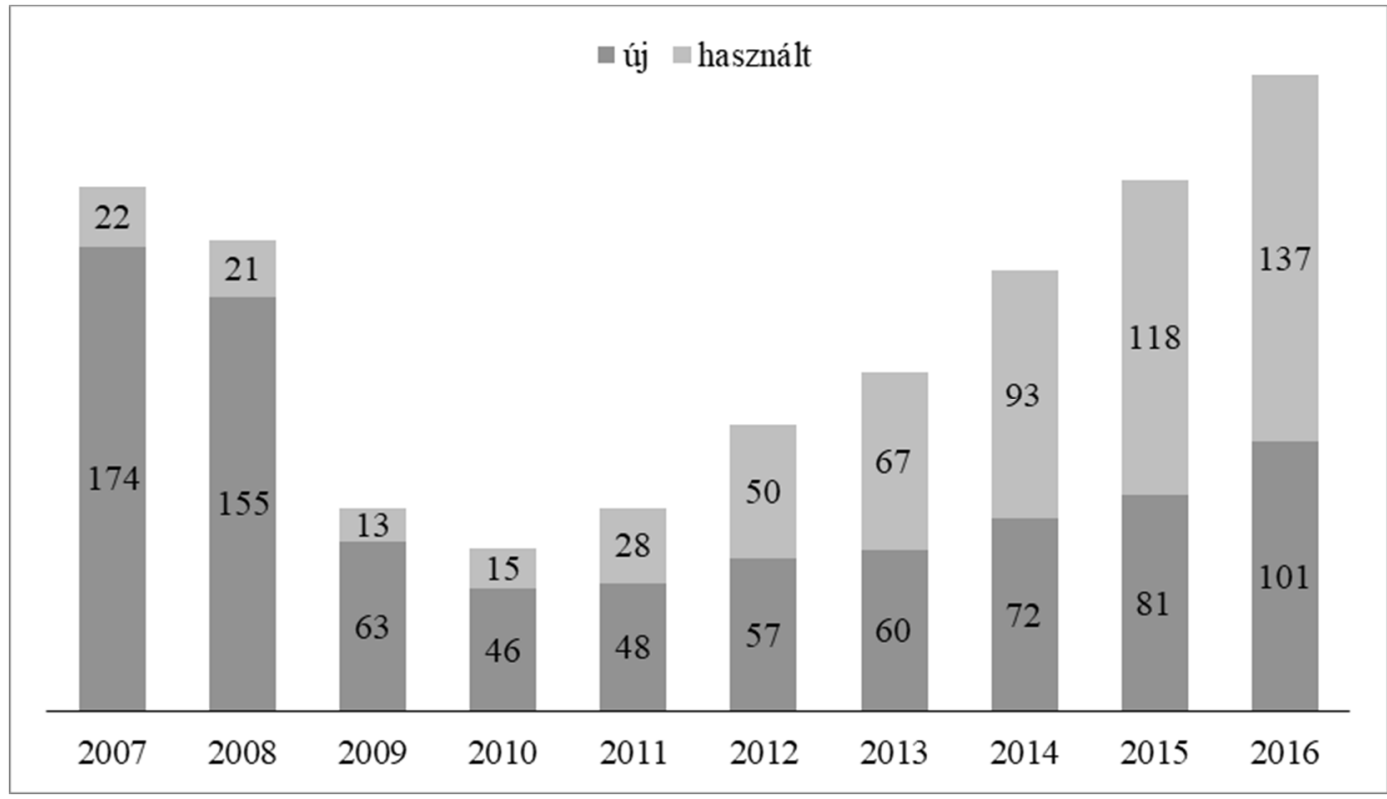

Forrás: Datahouse Kft. adatbázisa alapján saját szerkesztés.

A válság kirobbanását követő 5-6 évben az új autók értékesítése próbált a drasztikus csökkenést követően magához térni. Ezzel szemben a használtautók importja nagyon lendületesen növekedett, volt olyan év, amikor 70, illetve $80 \%$-os növekedést is elért. (Internet 2)

Ennek a rohamos emelkedésnek Magyarországon elsősorban az volt az oka, hogy a vevők nem rendelkeztek a szükséges anyagi fedezettel az új autók vásárlásához, így a használtautó-import felé fordultak. (Internet 3)

A jármüiparon belül, az autókereskedéseket tekintve, 2002-ben 1100 szalon foglalkozott új autók értékesítésével, az éves forgalmuk az 1500 milliárd forintot is meghaladta évente, 30-35 ezer munkavállalót alkalmazva. A kereskedelmhez kapcsolódó kiegészítő tevékenységekben a munkavállalók száma ekkor meghaladta az 50 ezer föt. A válságot követően, 2011-re csupán 420 kereskedés maradt, a szereplök száma is $60 \%$-kal csökkent. A csökkenés ellenére a márkakereskedések az egyik legjelentősebb adófizetők, és szakemberek ezreit foglalkoztatják mind a mai napig. Emellett a környezetvédelemben is élen járnak és a szelektív hulladékgyüjtést is az elsők között valósították meg. A beruházásokkal, szalonok építésével, és a járulékos befektetésekkel a gazdaságélénkítő folyamatoknak is meghatározó erői. A minőségi változásokra egyre nagyobb hangsúlyt fektetnek, hogy a verseny- és piacképességüket növelni tudják, az ügyfelek egyre magasabb szintü kiszolgálása érdekében, pedig egyre inkább a többmárkás kereskedések terjedtek el. (GÉMOSZ weboldala)

A márkák népszerüségéről elmondható, hogy 2017-ben a Suzuki volt a legnépszerübb Magyarországon. A második legnépszerübb márka a Ford volt, 
piacrésze közel 10\%-os. A harmadik helyen a Skoda végzett, az Opel a 4. helyre került, noha 2015-ben még az első helyen állt. Az 5. a Volkswagen, növekedése 2016-hoz képest $13 \%$ körüli. A Toyota 47,5\% növekedést mutatva 8139-re növelte eladásait. A Dacia 2016-hoz képest több mint 40\%-kal növelte az eladott autók számát. A sorrendben következő márkák már korántsem tudtak ilyen kiugró eladási eredményeket mutatni. A német prémium márkák szegmensében a Mercedes a legerősebb, az Audi és a BMW viszont szerényebb növekedést ért el 2017-ben. A Top15 hazai autómárka sorrendjét, az új autók alapján, és piaci részesedését foglalja össze az 1. táblázat.

1. táblázat: Személyautók márkasorrendje és piacrésze 2017-ben

\begin{tabular}{|c|c|c|c|c|c|}
\hline Sorrend & Márka & $\begin{array}{c}\text { 2017-es } \\
\text { eladott } \\
\text { darabszám }\end{array}$ & Piacrész & $\begin{array}{c}\text { 2016-os } \\
\text { eladott } \\
\text { darabszám }\end{array}$ & Piacrész \\
\hline 1. & Suzuki & 15161 & $13,04 \%$ & 11266 & $11,66 \%$ \\
\hline 2. & Ford & 11372 & $9,78 \%$ & 9522 & $9,86 \%$ \\
\hline 3. & Skoda & 10523 & $9,05 \%$ & 8755 & $9,06 \%$ \\
\hline 4. & Opel & 10189 & $8,76 \%$ & 9379 & $9,71 \%$ \\
\hline 5. & Volkswagen & 8546 & $7,35 \%$ & 7534 & $7,80 \%$ \\
\hline 6. & Toyota & 8139 & $7,00 \%$ & 5517 & $5,71 \%$ \\
\hline 7. & Dacia & 7329 & $6,30 \%$ & 5120 & $5,30 \%$ \\
\hline 8. & Renault & 5686 & $4,89 \%$ & 4896 & $5,07 \%$ \\
\hline 9. & $\mathrm{Kia}$ & 4507 & $3,88 \%$ & 3920 & $4,06 \%$ \\
\hline 10. & Nissan & 4257 & $3,66 \%$ & 3400 & $3,52 \%$ \\
\hline 11. & Hyundai & 3739 & $3,22 \%$ & 3174 & $3,29 \%$ \\
\hline 12. & $\begin{array}{l}\text { Mercedes- } \\
\text { Benz }\end{array}$ & 3733 & $3,21 \%$ & 2751 & $2,85 \%$ \\
\hline 13. & Fiat & 3221 & $2,77 \%$ & 3039 & $3,15 \%$ \\
\hline 14. & Audi & 2773 & $2,39 \%$ & 2502 & $2,59 \%$ \\
\hline 15. & BMW & 2698 & $2,32 \%$ & 2388 & $2,47 \%$ \\
\hline
\end{tabular}

Forrás: Autónavigátor (2017)

A GÉMOSZ a magyar márkakereskedések helyzetéről végzett 2017-es felmérése alapján elmondható, hogy folytatódnak Magyarországon a koncentrációs és konszolidációs folyamatok, ugrásszerü változások az elmúlt 2 évben nem történtek. Ezek alapján elmondhatjuk, hogy jelenleg 688 szalonban, 399 telephelyen folyik az új autó értékesítése, az eladások 38\%-kal nőttek 2015-höz képest.

$\mathrm{Az}$ értékesítési pontok számának növekedése összhangban van az új autó eladások harmadik éve tartó emelkedésével.

A tulajdonosok számát vizsgálva megállapíthatjuk, hogy 2015 óta körülbelül 6\%-kal csökkent a számuk, így most 234 tulajdonos kezében találhatóak a magyarországi kereskedések. A tulajdonosok számának csökkenését a GÉMOSZ három okra vezeti vissza:

- Egy márkás márkakereskedések bezárása

- Alapító visszavonulása 
- Kereskedés értékesítése

A felmérés megállapította azt is, hogy bár a tulajdonosok száma csökken, de a szalonok száma növekszik, hiszen egyre többen bővítik újabb és újabb márkával a kereskedésüket. Az autókereskedelmi helyszínek és szereplők főbb adatait a 2. ábra összegzi.

\section{2. ábra: Autószalonok, márkakereskedések és a tulajdonosok száma 2011-2017} között (db)

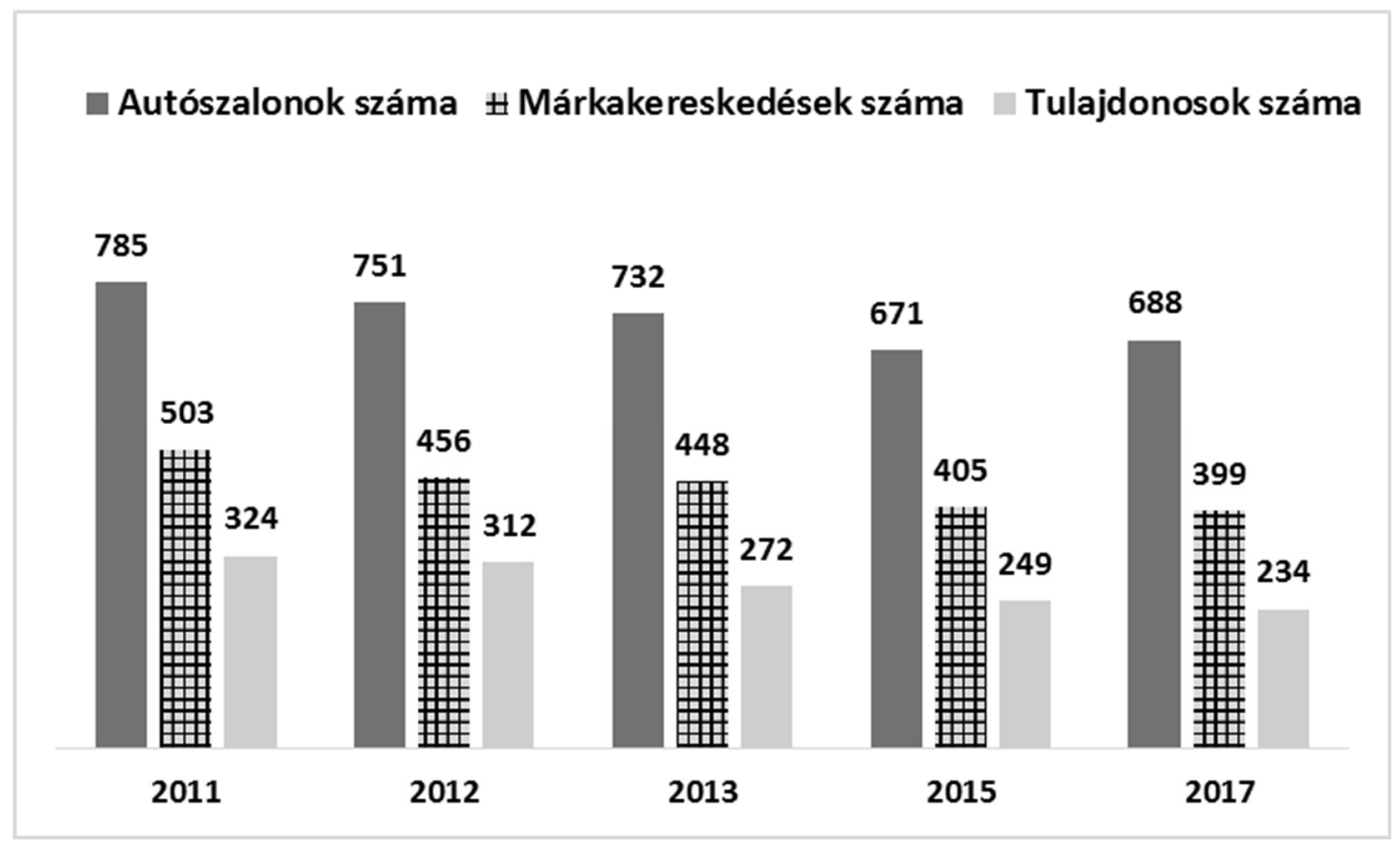

Forrás: GÉMOSZ adatközlése alapján saját szerkesztés.

\section{Anyag és módszer}

Kutatási céljaim eléréséhez első lépésben a GÉMOSZ-tól és a Datahouse Kft-től kapott „üzemsoros” primer adatbázis segítségével bemutattam és értékeltem az autóipar, azon belül pedig az autókereskedések jelenlegi szerepét és helyzetét Magyarországon.

Vizsgálatom során a szekunder adatok elemzését követően célzott primer kutatást is végeztem. A kereskedések stratégiájának és a válság hatásának, illetve a válság-kezelésének vizsgálatához a kérdőívezés módszerét alkalmaztam.

Módszerválasztásom során azt tartottam elsősorban szemelőtt, hogy a kérdőívezés során jól összehasonlítható és értelmezhető adatokat vizsgálhassak, amelyek jól lefedik az adott időszelet jellemzőit. A kérdőívek a GÉMOSZ támogatásával kerültek kiküldése az ország összes kereskedéséhez, így alapsokaságnak ezen kereskedéseket tekintem. 60 értékelhető kérdőívet kaptam vissza, ami a kereskedések $15 \%$-a. 


\section{Kutatásom eredményei}

A 2008-ban kirobbant válságot követően, a kereskedések életútja 3 irányba folytatódott. A cégek egy jelentős része bezárt, ami leginkább a Suzuki szalonok esetében volt megfigyelhető. A fennmaradt kereskedések egy része külső források bevonásával kívánt talpon maradni és túlélni, míg egy részük meg tudta ezt oldani a vállalaton belül, belső források segítségével is. Ezt támasztja alá a 3. ábra is, amin a külső források bevonását látjuk. Tőketársat a legvégső esetben vontak csak be a kereskedések, a kérdőív eredménye alapján elmondhatjuk, hogy csupán ketten alkalmazták ezt a finanszírozási formát.

\section{3. ábra: A válság kirobbanását követően a kereskedéseknél a külső források bevonása}

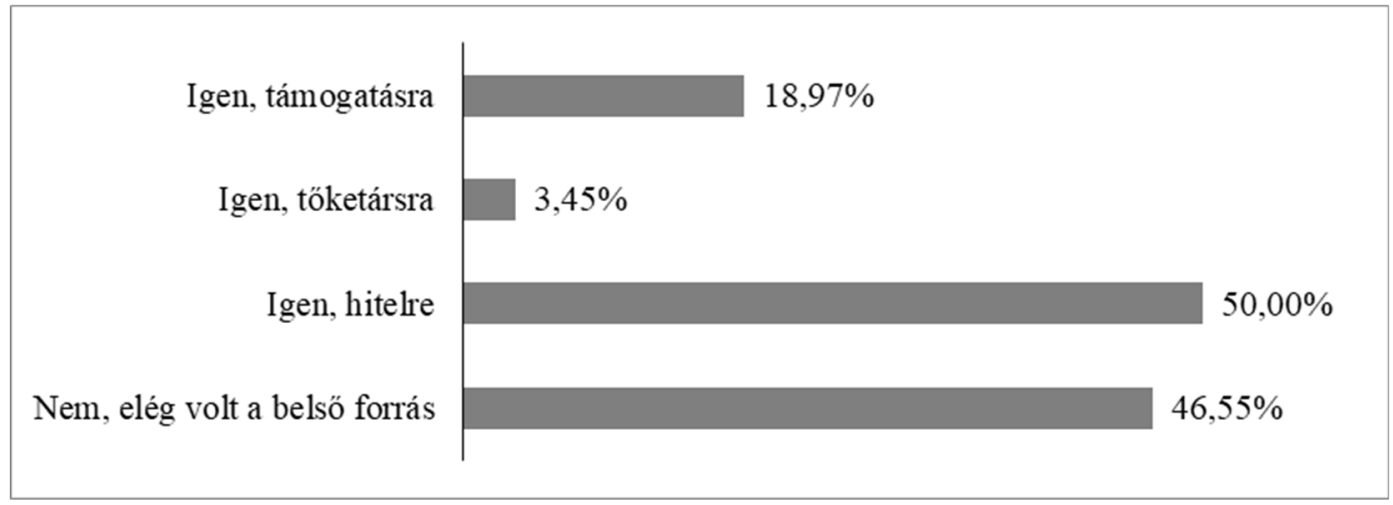

Forrás: A szerző saját szerkesztése.

Kutatásom során megvizsgáltam azt is, hogy milyen területeken kellett változtatnia a kereskedéseknek a válság kirobbanását követően a fennmaradáshoz, és milyen konkrét lépésekkel tudták ezt megvalósítani a tulajdonosok.

\section{4. ábra: A különböző területeken eszközölt változtatások aránya a válságot követően}

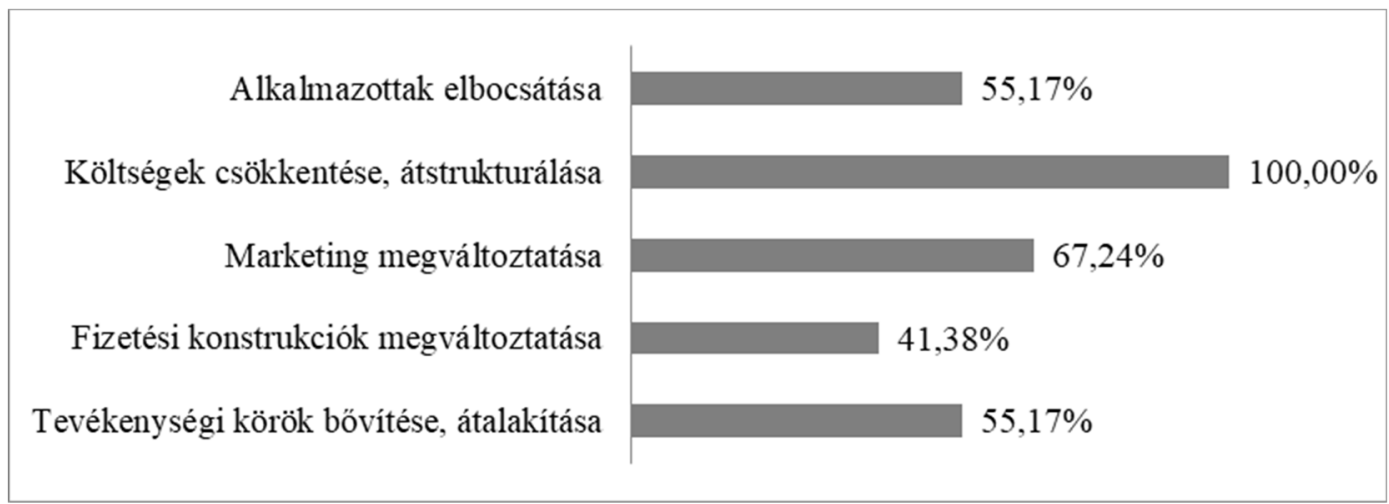

Forrás: A szerző saját szerkesztése. 
A 4. ábrán láthatjuk, hogy a válaszadó kereskedések mindegyike csökkentette, illetve átstrukturálta költségeit, és több, mint a kétharmaduk a marketinget is megváltoztatta. A vizsgált vállalatoknak több, mint a fele a tevékenységi körét alakította át, illetve ugyanekkora arányban bocsátották el az alkalmazottakat. A világgazdasági válságot követően egy amerikai kutatás (Internet 4) is hasonló eredményre jutott, ezeket a változtatásokat a tengerentúlon is alkalmazták a válságot követöen.

A 2008-as világgazdasági válság kirobbanását követően a szalonok száma közel 40\%-val esett vissza, ebből fakadóan megvizsgáltam azon tulajdonságokat, illetve tevékenységeket is, amelyek segítséget nyújtottak, illetve közrejátszottak abban, hogy azok a vállalkozások, amik fennmaradtak, túléljék ezt az időszakot. A választási arányokat az 5. ábra szemlélteti. Látható, hogy a válaszadók körülbelül $90 \%$-a a jó pénzgazdálkodást jelölte meg olyan tulajdonságnak, ami miatt sikerült a válságot túlélniük, de közel 75\% a jó vevőszolgálatot is fontos jellemzőnek tartotta.

\section{5. ábra: A válság túlélését elősegítő tulajdonságok, tevékenységek}

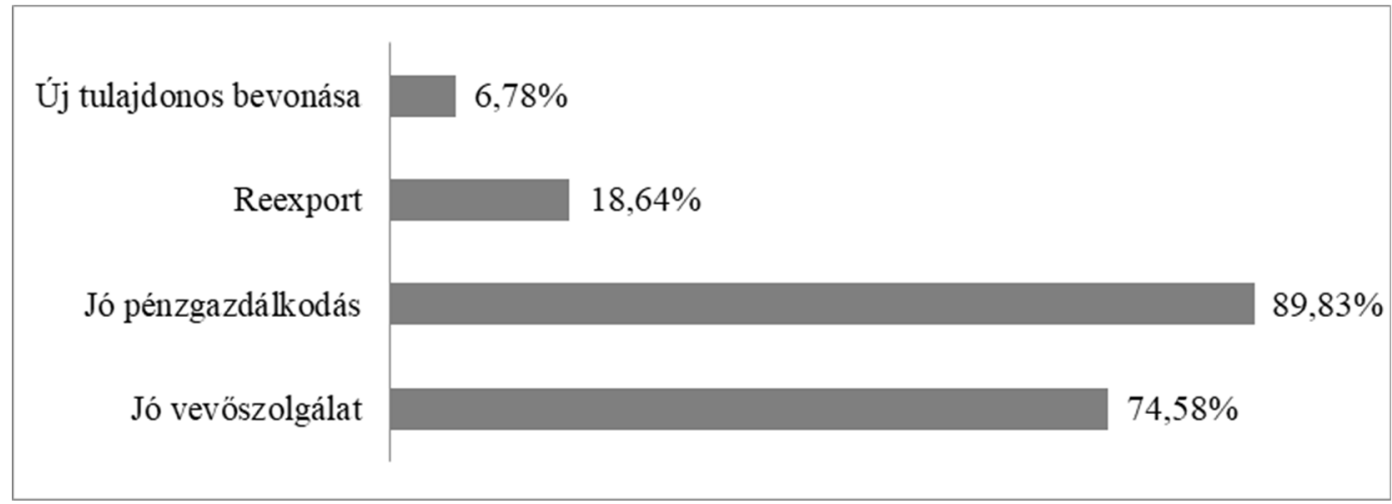

Forrás: A szerző saját szerkesztése.

A válság túlélését segítő tevékenységek mellett megpróbáltam feltérképezni azokat az okokat, illetve tulajdonságokat is, amik miatt a megszünt kereskedések bezártak. Szerettem volna személyesen is mélyinterjút készíteni ilyen kereskedések tulajdonosaival, de ez elöl teljesen elzárkóztak, így a még müködő kereskedések véleményeire tudtam hagyatkozni. Az ő elmondásuk és válaszaik, bár csak közvetetten, de mégis adott egy képet arról, milyen hiányosságaik lehettek azon vállalkozásoknak, akik nem élték túl a válságot.

A kérdéskört két irányból közelítettem meg. Egyrészt rákérdeztem arra, mit gondolnak a kereskedés tulajdonosai/vezetői, mi lehet általánosságban elmondható iparági hiányosság, illetve mi az, ami csak a hasonló kereskedésekre jellemző.

A választási arányok teljesen hasonlóan alakultak mind a két esetben, ami megfigyelhetö a 6. ábrán. A legtöbben a nem megfelelö vezetést jelölték meg, amit a jutalék előre történő elköltése követett. Közel 50\%-a a kérdőív kitöltőinek mondta, hogy a nem megfelelő vevőszolgálat, illetve a kereskedés fiatal kora az, ami miatt nem élték túl a vállalkozások ezt az időszakot. 


\section{6. ábra: A kereskedések bezárását okozó tulajdonságok és okok a válságot követően}

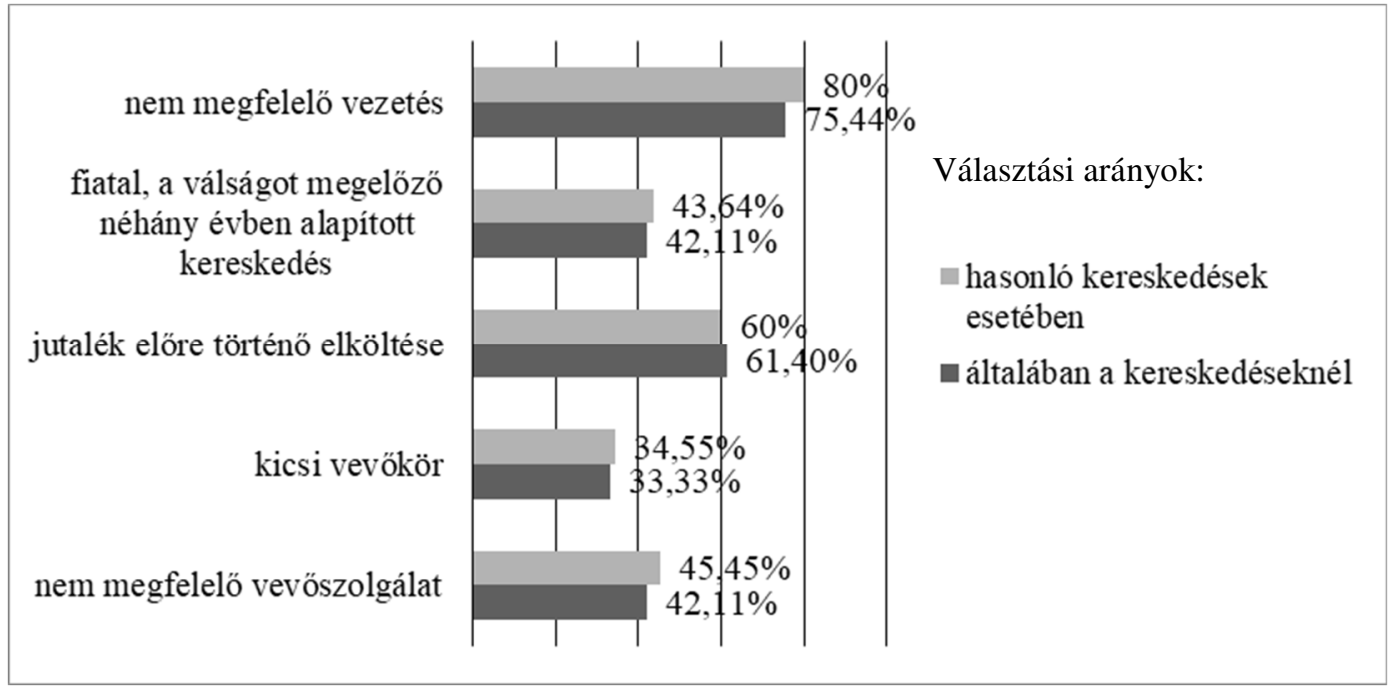

Forrás: A szerző saját szerkesztése.

A 2000-es évek elején a szalonnyitási program miatt nagyon sok márkakereskedés nyílt, akiknek viszont nem volt meg vagy a megfelelő szakmai vagy pénzügyi hátterük, elsősorban az értékesítésre fókuszáltak csak, így viszont a világgazdasági válság kirobbanását követően nem volt elég erejük, tapasztalatuk, vevőkörük és múltjuk a túléléshez.

A kérdőívben kértem a kereskedéseket, hogy rangsorolják azokat a tényezőket, amik a sikerességüket szerintük befolyásolják.

A válaszok alapján elmondhatjuk, hogy nincs nagymértékü egyetértés a válaszadók között, nagyon nagy a szóródás. Két tényezö, a tőke, illetve az értékesítés és vevőszolgálat, amit a legtöbben az utolsó helyre tettek, míg a speciális eszközök és gépek azok, amik a legfontosabbak a válaszadók 42\%-a szerint (7. ábra). 


\section{7. ábra: A siker tényezőkön belüli rangsor megoszlása}

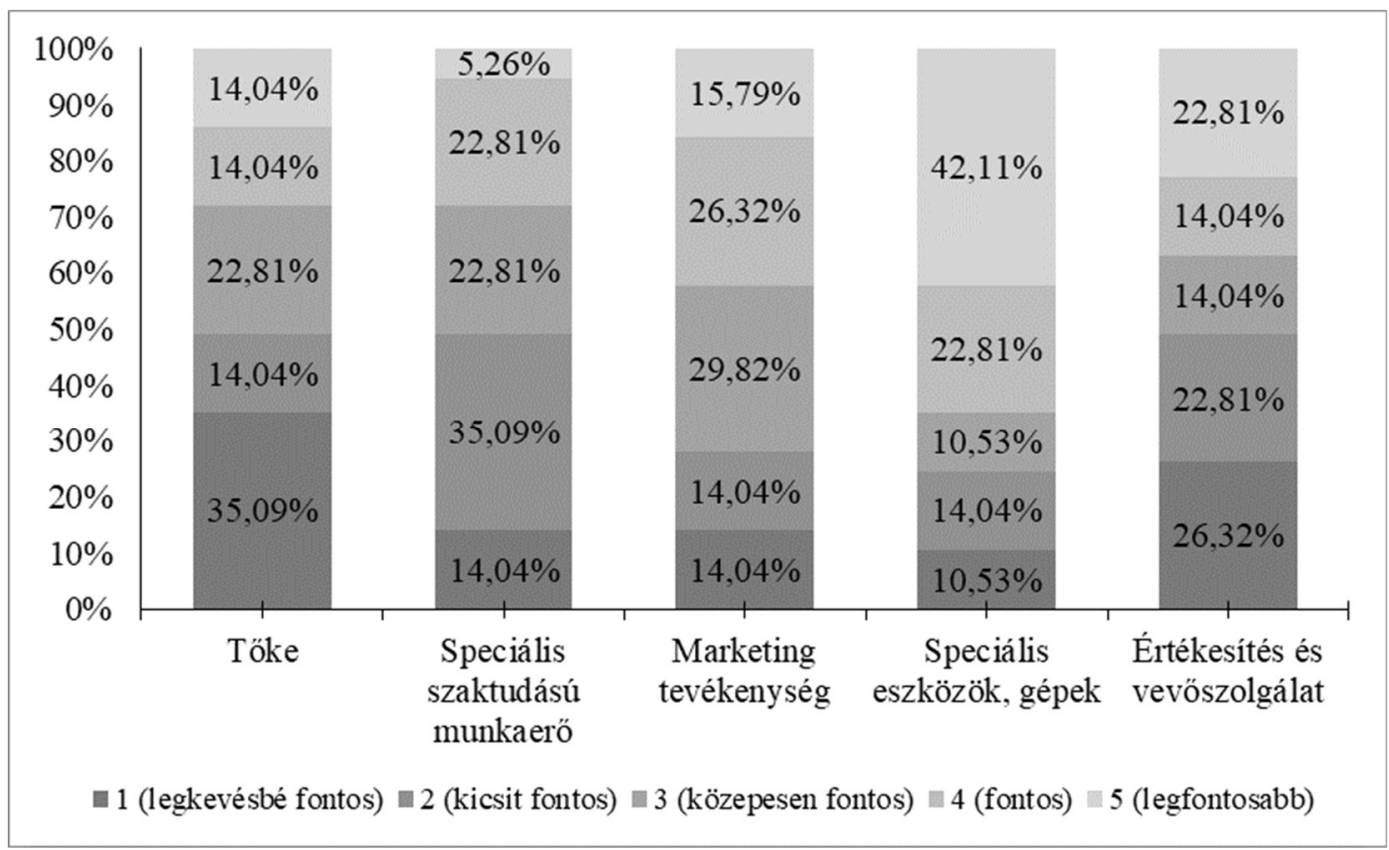

Forrás: A szerző saját szerkesztése.

A rangszámok átlaga alapján a tényezők közötti sorrendben a speciális eszközök és gépek kerültek az első helyre, vagyis ezt tartják a legfontosabbnak a kereskedések tulajdonosai a sikeresség szempontjából. A speciális szaktudás csak a 4. lett, míg a marketingtevékenység a 2 . helyre került, holott a válságot követöen a legtöbb kereskedés pont ezen költségek csökkentésével és átstrukturálásával próbálta a válságot túlélni.

Kutatásom során azt is megvizsgáltam, hogy a kereskedések szerint mik azok a kockázati tényezők, amik a jövőben negatívan befolyásolhatják az iparágat és a vállalkozások versenyképességét. 1-től 5-ig terjedő skálán kértem, hogy súlyozzák ezeket, a jelentéktelentől egészen a legnagyobb jelentőséggel bíróig (8. ábra). 


\section{8. ábra: Az iparágban a kockázati tényezők jelentőségének százalékos aránya}

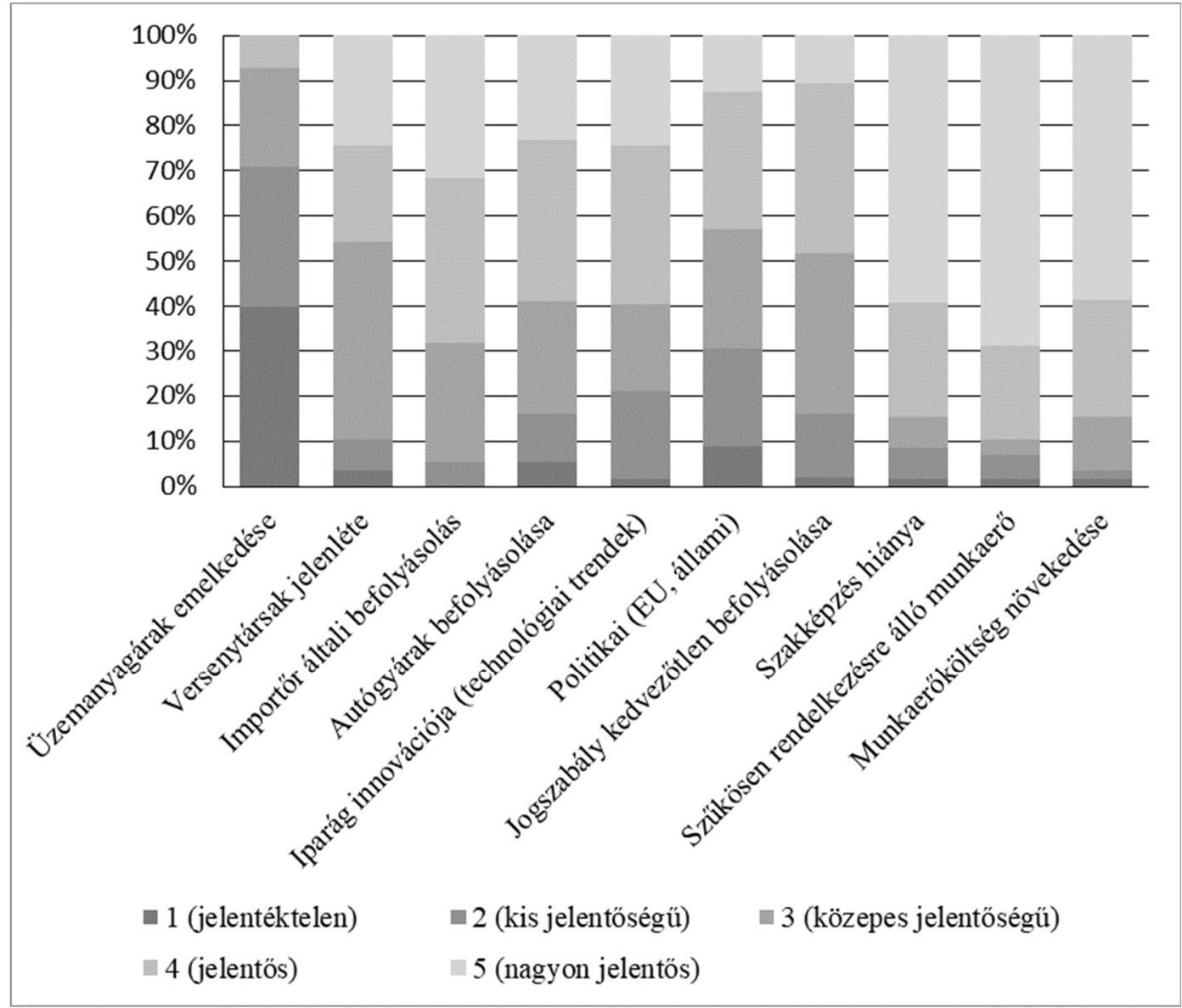

Forrás: A szerző saját szerkesztése.

A 8. ábrán láthatjuk, hogy a munkaerővel kapcsolatos tényezőket tartják leginkább kockázatosnak a kereskedések vezetői és tulajdonosai, vagyis a szükösen rendelkezésre álló munkaerőt, a szakképzés hiányát, illetve a munkaerőköltség növekedését. Ezen tényezőket a válaszadó tulajdonosok és/vagy vezetők 60-70\%-a tartotta a legjelentősebb kockázati forrásnak. Ezen hármast az importőrök általi befolyásolás követ, amit márka és telephely számától, tulajdonostól, vezetőtől függetlenül szintén mindenki megemlített.

Megfigyelhető az is, hogy az üzemanyagárak emelkedése jelenti szerintük az iparágra nézve a legkisebb kockázatot, vagyis véleményük szerint az autókereskedelemre nincs és nem lesz hatással az, hogy az üzemanyagárak hogyan változnak.

A kockázati tényezők jelentőségének feltárását követően a következőkben azt tanulmányoztam, hogy ugyanakkor, amikor stratégiát készítenek a kereskedések, milyen kockázati tényezőket vesznek figyelembe.

Az előző kérdés (a kockázati tényezőkre vonatkozó) eredményei alapján a kereskedéseknek leginkább a hiányos szakképzéssel és a szükösen rendelkezésre álló 
munkaerővel kellene számolniuk a tervezésnél. Az erre vonatkozó kérdés válaszait a 9. ábra mutatja.

\section{9. ábra: A stratégia készítésénél figyelembe vett kockázati tényezők a vizsgált vállalkozásoknál}

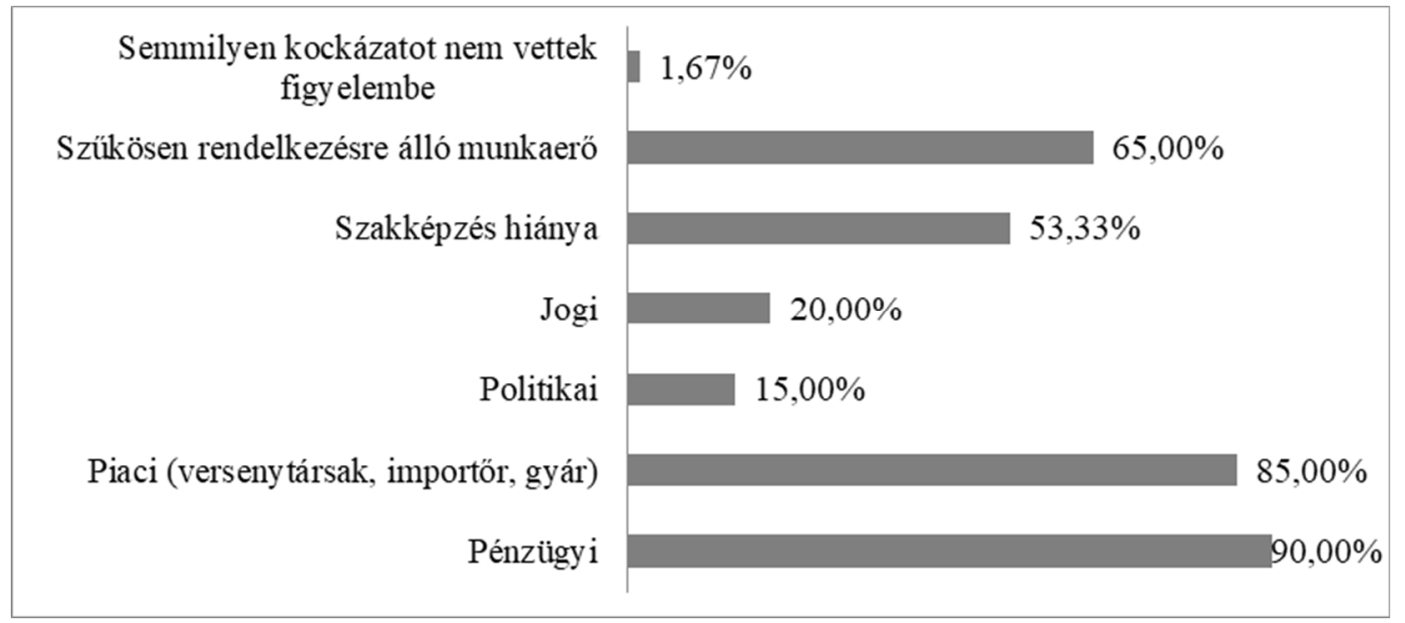

Forrás: A szerző saját szerkesztése.

Ugyanakkor azt látjuk, hogy magasan a pénzügyi és a piaci kockázatokat veszik figyelembe, amikor a stratégiáról döntenek a vezetők. Vagyis sokkal fontosabb és jelentősebb kockázatnak számít a tervezés során például a versenytárs, az importőr vagy a gyárak irányából érkező változások vagy változtatások, csak ezután következnek a munkaerővel kapcsolatos tényezők. Kutatásom előző fázisai, korábbi tapasztalataim alapján viszont azt gondolom, hogy ez az eredmény azért lett eltérö az elöbb vizsgált kockázati tényezőkhöz képest, mert a tervezés során rövid távra, leginkább az éves tervekre fókuszálnak a vezetők. Az éves terveken belül pedig az értékesítésre, illetve a fejlesztési lehetőségekre, feladatokra, amit viszont leginkább a pénzügyi és a piaci (versenytárs, importőr, gyár) helyzet befolyásol.

\section{Következtetések}

A kérdöív eredményei, illetve a szakirodalmak alapján az iparágban egy sajátos helyzet és jövőkép látszik kirajzolódni, amely egyelőre ellentmondásos.

A kereskedések és az importörök (Suzuki esetében a gyár) érdekei összeütköznek, ezenkívül az iparág átalakulásával a jövőkép is ambivalenssé válik ezen érdekekkel szemben. Az elmúlt években megfigyelhetö volt, hogy az importörök inkább támogatták az egy márkát és egy telephelyen müködö kereskedések, mint a több márkásakat, a korábban nyitott autóplázák pedig zömmel megszüntek Magyarországon. Ugyanakkor nagyon sok márka esetében megfigyelhetö és könnyen belátható, hogy önmagukban fenntarthatatlanok és a tulajdonosok kénytelenek további márkákat is bevonni az adott kereskedés termékpalettájába. Ezt támasztja alá az is, hogy a márkakereskedések száma az évek 
óta növekvő piac ellenére sem növekedett, ami azt jelzi, hogy a tulajdonosok inkább újabb márkákat vállalva és a már meglévő telephelyeiket kihasználva fejlődtek.

Ugyanakkor a 2008-ig több márka esetében is megfigyelhető volt (a Suzukin kívül) az egy márkás kereskedések nagyobb aránya, ilyenek voltak például a Nissan, a Seat vagy a Honda szalonok. Azok, akik ezekből a kereskedésekből nem élték túl a világgazdasági válságot és tönkrementek arra volt visszavezethető, hogy a vásárló igény nagyon lecsökkent és üresek lettek az említett szalonok, városon belül, viszonylag közel egymáshoz nem tudtak megélni az ilyen jellegü vállalkozások.

A jövőben egyre fontosabbá válik az autókereskedések számára, hogy a vásárlókkal egy szoros kapcsolatrendszert alakítsanak ki és próbáljanak minél inkább az új mobilitási trendekhez alkalmazkodni. A digitális élmény, az autókereskedés elhelyezkedése, az internetelérhetőség, illetve a vásárlást követő élmény mind mind egyre inkább befolyásoló tényező lesz az autókereskedések versenyképességét illetően. Egy felmérés szerint a vásárlók interneten való tájékozódása 2000-ben még csak $15 \%$ volt, ez az arány viszont 2016-ra megközelítette a 90\%-ot. (Mohr, 2013; Gagel, 2014; Deloitte, 2017) Az elkövetkező években pedig az újabb internetalapú üzleti modellek kialakulásával nemcsak a tájékozódás, hanem többek között a kapcsolatfelvétel és a kereslet - kínálat összekapcsolódása is digitális platformon keresztül zajlik majd. (Buda-Lehota, 2017)

\section{Köszönetnyilvánítás}

Köszönöm Gablini Gábor úrnak, Lukács Eszternek, a GÉMOSZnak és a Magyar Autós Szakmai Szövetségnek a sok támogatást és segítséget, és köszönettel tartozom a Datahouse Kft. munkatársainak, hogy rendelkezésemre bocsátották az elemzésekhez szükséges adatbázisokat. Köszönöm továbbá azon autómárkakereskedéseknek az idejét és segítségét, akik a kérdöívek során készségesen álltak rendelkezésemre.

\section{Irodalomjegyzék}

Autónavigátor (2017): Több mint százezer autó kelt el 2017-ben. <https://www.autonavigator.hu/ cikkek/tobb-mint-szazezer-auto-kelt-el-2017-ben>. (2018.07.11.)

Buda G., Lehota J. (2017): Az internetalapú közösségi gazdálkodás formái. Gazdaság és Társadalom, 9 (2): $23-46$.

Datahouse Kft. adatbázisa.

Deloitte (2017): Automotive customer service becomes a relationship-based consumer experience: Dealers should prepare now for a new mobility. <https://www2.deloitte.com/us/en/pages /manufacturing/articles/relationship-basedautomotive-consumer-experience-and-customer-ser vice.html>. (2017.03.27.)

Gagel R. (2014): Five Reasons Why Too Many Auto Dealers Will Fail. <https://www.linkedin.com/ pulse/20141203152326-76658889-five-reasons-why-toomany-auto-dealers-will-fail>. (2017. 03.29).

GÉMOSZ adatbázisa és weboldala. <www.gemosz.hu>.

Internet 1: <http://greenfo.hu/hirek/2017/03/18/egyre-oregebb-a-magyar-autoallomany>. (2019.01. 22.) 
Internet 2: <https://www.napi.hu/magyar_vallalatok/valtozas_elott_all_a_magyar_hasznaltauto_pi ac.652691.html>. (2019.01.22.)

Internet 3: <https://www.napi.hu/nemzetkozi_gazdasag/nagy_a_baj_a_hasznaltauto_piacon_szigori tana_az_eu.666134.html>. (2019.01.22.)

Internet 4: <https://www.autonews.com/article/20180924/RETAIL07/180929976/40-ways-to-copewith-a-crisis $>$. (2019.01.31.)

Mohr D. (2013): The road to 2020 and beyond: What's driving the global automotive industry? McKinsey\&Company, Stuttgart. 28.

Pásztor S. (2011): Kódolt kifulladás: Válság a gépjármüpiacon. Közgazdasági szemle, 58 (2): 173189. 